\title{
HUBUNGAN EFIKASI DIRI KARIR DENGAN KEMATANGAN KARIR PADA SISWA KELAS XII SMKN 2 JEPARA
}

\author{
Ribka Desy Ariana \\ Fakultas Psikologi Universitas Kristen Satya Wacana \\ ribkaariana96@gmail.com \\ Christiana Hari Soetjiningsih \\ Fakultas Psikologi Universitas Kristen Satya Wacana \\ soetji_25@yahoo.co.id
}

\begin{abstract}
Abstrak
Penelitian ini bertujuan untuk mengetahui ada tidaknya hubungan positif yang signifikan antara efikasi diri karir dengan kematangan karir pada siswa kelas XII SMKN 2 Jepara. Hipotesis dari penelitian ini yaitu adanya hubungan yang positif signifikan antara efikasi diri karir dengan kematangan karir pada siswa kelas XII SMKN 2 Jepara. Jumlah populasi dalam penelitian ini yakni 451 siswa dengan jumlah sampel 171 siswa. Variabel efikasi diri karir diambil dengan menggunakan skala career decision making self-efficacy, sedangkan kematangan karir menggunakan career maturity inventory. Analisis data dengan menggunakan teknik korelasi product moment. Hasil penelitian menunjukkan adanya hubungan yang positif signifikan antara efikasi diri karir dengan kematangan karir pada siswa kelas XII SMKN 2 Jepara, dengan $r=0,381$ dengan $p<0,05$.
\end{abstract}

Kata kunci : Efikasi Diri Karir, Kematangan Karir, Siswa.

\begin{abstract}
This study aims to determine whether there is a significant positive correlation between career self efficacy and career maturity in twelfth graders students at SMKN. 2 Jepara. The hypothesis of this study is that there is a significant positive correlation between career self efficacy and career maturity in twelfth graders students at SMKN. 2 Jepara. In total there are 451 students and 171 students were participate. Variable career self efficacy were collected using career decision making self-efficacy scale by Taylor Betz and variable career maturity were collected using career maturity inventory by Crites. Data were analyzed using correlation product moment. The result shows $r=0,381$ with $p<0,05$ which means there is significant positive correlation between career self efficacy and career maturity in twelfth graders student at SMKN. 2 Jepara.
\end{abstract}

Keywords: Career self efficacy, Career maturity, Student. 


\section{PENDAHULUAN}

Sekolah Menengah Kejuruan (SMK) merupakan salah satu lembaga pendidikan menengah yang mempunyai misi menyiapkan tenaga kerja tingkat menengah yang terampil dan berkompeten sesuai dengan bidang keahliannya yang diproyeksikan untuk mengisi lapangan kerja di dunia usaha maupun dunia industri. Siswa SMK mulai mengenal karir atau pekerjaan dari lingkungan keluarga, lingkungan masyarakat dan lingkungan sekolah. Tugastugas perkembangan bagi siswa di sekolah sebagai calon tenaga kerja ialah memilih lapangan kerja yang sesuai dengan potensi-potensi yang dimilikinya. Potensi-potensi yang dimaksud antara lain adalah pengetahuan, keterampilan berpikir, kemampuan kerja, dan sikap terhadap pekerjaan. Namun pada kenyataannya saat lulus sekolah siswa dihadapkan pada banyak situasi pilihan misalnya melanjutkan studi ke perguruan tinggi, memiliki usaha sendiri, atau harus memasuki dunia kerja (PP RI No. 29 th 1990).

Salah satu institusi sekolah yang mempersiapkan siswanya untuk mampu terjun langsung ke dunia kerja setelah lulus adalah SMK. Kematangan karir bagi siswa SMK sangatlah penting, karena salah satu permasalahan yang dialami siswa SMK setelah menyelesaikan studinya adalah menyangkut pemilihan karir dan pekerjaan. Kualitas pemilihan karir ditentukan oleh tingkat kematangan karir yang dimiliki individu. Komandyahrini (dalam Aji, 2010). Oleh karena itu kematangan karir sangat dibutuhkan oleh siswa agar mereka dapat memilih dan mempersiapkan diri memasuki karir dengan baik.

Penelitian Prihantoro (2007) yang menyebutkan siswa kelas X SMAN 2 Majalengka sebagian besar memiliki kemampuan merencanakan karir yang rendah yaitu 27,8\%. Penelitian tersebut juga diperoleh data bahwa dari sembilan kemampuan yang harus dimiliki oleh remaja dalam merencanakan karir, kemampuan dalam hal kemandirian pengambilan keputusan karir adalah yang terendah. Hal ini menunjukkan bahwa kematangan karir siswa SMA masih rendah, dimana pengetahuan dan keinginan untuk memperoleh informasi dan wawasan tentang studi lanjutan serta kemampuan dalam pengambilan keputusan yang berkaitan dengan studi lanjut atau karir masih belum dapat diandalkan guna menentukan karir yang akan dijalaninya kelak. Hal ini didukung juga dengan hasil wawancara peneliti terhadap 10 siswa kelas XII di SMKN 2 Kab. Jepara, lima orang siswa kelas XII masih mengalami kebingungan hendak melanjutkan kemana atau mengambil jurusan apa di perguruan tinggi karena belum memikirkannya. Saat ditanya jika sudah lulus ingin melanjutkan kuliah dimana, siswa tersebut mengaku masih bingung dan tidak tahu harus mengambil jurusan apa yang sesuai untuk dirinya. Sementara lima yang lainnya sudah merasa yakin dan mampu untuk memutuskan hendak kemana arah karir yang akan dicapai. Saat ditanya siswa tersebut mengatakan ada yang mau mengambil jurusan desain komunikasi visual di Universitas Dian Nuswantoro, ada juga yang langsung bekerja di meubel. 
Crites (1973) mendefinisikan kematangan karir sebagai tingkat yang dimiliki saat individu telah menguasai tugas perkembangan karirnya, baik komponen pengetahuan maupun sikap, yang sesuai dengan tahap perkembangan karir. Tahap perkembangan karir siswa SMK ada pada tahap eksplorasi 15-24 tahun. Super (dalam Zulkaida, 2007). Kematangan karir meliputi pengetahuan akan diri, pengetahuan akan pekerjaan, kemampuan memilih suatu pekerjaan, dan kemampuan untuk merencanakan langkah-langkah menuju karir yang diharapkan. Crites (dalam Zulkaida, 2007). Para remaja dapat memilih karir yang tepat, dalam hal ini adalah keputusan tentang pendidikan lanjutan, siswa memerlukan tingkat kematangan karir yang baik, karena tingkat kematangan karir akan mempengaruhi kualitas pemilihan karir.

Dimensi dari kematangan karir menurut Crites (1973) ialah (a) Konsistensi pemilihan karir, mengandung aspek-aspek kemampuan pengambilan keputusan terhadap karir yang dipilihnya, kemampuan yang dimaksut berhubungan dengan tingkat kesesuaian karir, pemilihan karir dalam berbagai pengaruh dari keluarga, (b) Realisme dalam pemilihan karir, mengandung aspek kesesuaian antara realisme dan kemampuan karir yang dipilihnya, mampu mengambil keputusan untuk memilih karir yang sesuai dengan sifat kepribadiannya dan dapat menyesuaikan antara tingkat status sosial ekonomi dengan karir yang dipilihnya, (c) Kompetensi pemilihan karir, memiliki aspek-aspek mengenai kemampuan individu dalam memecahkan permasalahan yang berhubungan dengan pemilihan karir, rencana yang berhubungan dengan pemilihan karir, memiliki pengetahuan mengenai karir yang dipilihnya, dan mengevaluasi kemampuan diri dalam hubungannya dengan pemilihan karir, (d) Sikap dalam pemilihan karir mengandung aspek-aspek tentang keaktifan individu dalam proses pengambilan keputusan bersikap dan berorientasi positif terhadap karir dan nilai-nilai pekerjaan yang dipilih, tidak tergantung pada orang lain dalam memilih karir.

Ada beberapa hal yang dapat memengaruhi kematangan karir. Menurut Partino (2005) kematangan karir dipengaruhi oleh beberapa faktor diantaranya konsep diri, efikasi diri, prestasi akademik, kebebasan. Menurut Super (2001) mengatakan bahwa pemilihan karir merupakan implementasi dari pemahaman diri dalam ketersediaan lapangan kerja, salah satu aspek yang memiliki hubungan relevan untuk mempelajari kematangan karir individu adalah efikasi diri. Menurut Super (1990) terdapat kemungkinan seseorang kurang percaya dan kurang yakin dengan kemampuannya sendiri untuk membuat karir tertentu atau keputusan karir. Perasaan ragu-ragu dan tidak dapat menentukan serta memutuskan pilihan untuk memasuki dunia kerja, salah satunya diakibatkan karena tidak memiliki keyakinan terhadap kemampuan dirinya sendiri.

Hal ini didukung dari wawancara yang dilakukan peneliti dengan guru BK SMK. Guru BK mengatakan bahwa siswa kelas XII SMKN 2 Kab. Jepara cenderung akan memikirkan kelanjutan studi mereka ketika sudah lulus. Mereka belum memikirkan dan belum yakin atas 
kemampuannya mengenai keputusan studi lanjutan yang akan mereka ambil lebih awal, sehingga hanya sedikit waktu yang dapat siswa gunakan untuk benar-benar memikirkan masa depan mereka. Hal diatas membuktikan betapa kurangnya efikasi diri karir. Namun, ada beberapa siswa yang sudah memiliki efikasi diri karir yang baik. Mereka sudah memiliki keyakinan terhadap kemampuan dirinya sendiri. Guru BK mengatakan bahwa beberapa dari siswa kelas XII SMKN 2 Kab. Jepara ada yang aktif berkunjung ke ruang BK untuk mencari informasi mengenai karir, siswa sudah bisa menentukan arah pendidikan atau karir yang akan ditempuh selanjutnya. Siswa tersebut sudah mencari-cari informasi dari orang tua, teman sebaya, dan orang-orang sekitarnya mengenai informasi pendidikan seperti kuliah dan informasi mengenai pekerjaan yang sesuai dengan kemampuan diri mereka sendiri. Dalam tugas perkembangan, usia mereka sudah dapat menemukan potensi yang dimilikinya untuk mengembangkan sebagai karir masa depan.

Hacket dan Betz (dalam Bandura, 1997) merupakan orang yang mengembangkan teori efikasi diri karir dengan menerapkan konsep efikasi diri untuk perilaku yang berhubungan dengan karir. Karir dapat didefinisikan sebagai kombinasi dan urutan peran pekerjaan yang seseorang alami selama seumur hidup (Super, 1980). Efikasi diri karir tidak memiliki makna utuh dari para ahli. Dengan demikian definisi dari efikasi diri karir adalah keyakinan atau kepercayaan individu terhadap kemampuannya untuk mencapai tugas karir yang harus dilalui sesuai rentang usia perkembangan karir yang dihadapi.

Dimensi dari efikasi diri karir menurut Taylor dan Betz (1983) (dalam Bandura, 1997) ialah: (a) self-appraisal (penilaian diri), menjelaskan bagaimana gambaran self efficacy siswa melalui penilaian terhadap diri individu sendiri, (b) gathering occupational information (pengumpulan informasi bidang karir), melihat seberapa jauh siswa yakin akan kemampuannya untuk bidang karir tertentu dengan mengumpulkan informasi yang dibutuhkan, dan dilihat dari pengumpulan informasi tentang bidang karir yang diminati, (c) goal selection (seleksi tujuan), dilihat dari keyakinan terhadap tujuan yang akan dicapai pada bidang karir yang diminati, dan merasa percaya bahwa tujuan pada bidang karir tertentu pasti dapat diwujudkannya, (d) planning for the future (rencana masa depan), menjelaskan bagaimana siswa memiliki tingkat kepercayaan terhadap rencana masa depan yang akan dibuat untuk memilih bidang karir tertentu, dan percaya bahwa rencana masa depan yang dibuat mampu diwujudkan, (e) problem solving (pemecahan masalah), menggambarkan keyakinan siswa akan mampu menyelesaikan masalah dengan baik.

Menurut Widjaja (dalam Susantoputri, 2014) dalam proses mencapai kematangan karir, seseorang perlu mempunyai keyakinan tentang dirinya, yakin dengan ciri-ciri kepribadian yang menonjol, memiliki keyakinan akan potensi intelektualnya, dan yakin dengan kelebihan yang dimiliki yang membedakannya dari siswa yang lain dan dapat menerima perbedaan tersebut. Siswa tersebut harus menentukan dengan tepat bidang karir atau jenis 
pekerjaan yang sesuai dengan mereka. Menurut Schunk (dalam Pajares, 2006) efikasi diri mempengaruhi siswa dalam memilih kegiatannya termasuk mempersiapkan kematangan karirnya. Siswa dengan efikasi diri yang rendah mungkin menghindari mata pelajaran yang banyak tugasnya, khususnya untuk tugas-tugas yang banyak tantangan atau memiliki kesulitan yang tinggi, sedangkan siswa dengan efikasi diri yang tinggi mempunyai keinginan besar untuk mengerjakan tugas-tugasnya. Rendahnya kematangan karir dapat menyebabkan kesalahan dalam mengambil keputusan karir, termasuk kesalahan dalam menentukan jurusan pendidikan bagi siswa SMK (Wijaya 2010). Hasil penelitian Nathalia (dalam Lestari, 2013) menyimpulkan beberapa ciri orang yang memiliki efikasi diri karir yang tinggi antara lain suka memikul tanggung jawab secara pribadi dan menginginkan hasil yang diperoleh dari kemampuan optimalnya. Individu juga suka pada tantangan dan tidak suka melakukan tugas yang mudah atau sedang. Selain itu, individu sangat menghargai waktu, memiliki daya kreativitas dan inovatif yang tinggi dalam mencari cara mengatasi masalah, menyukai segala sesuatu yang mengandung resiko karena individu percaya diri dan yakin bahwa dirinya mampu melakukan sesuatu meskipun sulit.

Hasil penelitian sebelumnya yang dilakukan oleh Widjaja (dalam Susantoputri, 2014) menunjukkan bahwa ada hubungan positif yang sangat signifikan antara efikasi diri dengan kematangan karir. Namun, penelitian yang dilakukan oleh Rachmawati (2012) memberikan hasil yang kontradiksi dari beberapa penelitian yang telah dijelaskan sebelumnya dimana hasil penelitian tersebut menunjukkan bahwa tidak ditemukan adanya hubungan antara efikasi diri dengan kematangan karir. Dalam penelitian Sersiana (2013) mengatakan bahwa efikasi diri karir berperan penting dalam kematangan karir. Peningkatan efikasi diri karir dapat membantu siswa dalam menentukan dan mengambil keputusan karir secara tepat. Semakin tinggi efikasi diri karir individu, maka semakin keras individu tersebut berusaha dan semakin tinggi motivasinya. Sebaliknya semakin rendah efikasi diri karir individu maka semakin rendah usaha yang dilakukan oleh individu dan semakin rendah pula motivasinya untuk mencapai kematangan karir. Bandura (dalam Warsito, 2009) mengatakan bahwa individu yang memiliki efikasi diri karir yang rendah akan menghindari semua tugas dan menyerah dengan mudah ketika masalah muncul. Mereka menganggap kegagalan sebagai kurangnya kemampuan yang ada. Dalam kaitannya dengan keyakinan akan kemampuan ini, orang yang memiliki efikasi diri karir yang tinggi akan berusaha atau mencoba lebih keras dalam menghadapi tantangan untuk mencapai kematangan karir sebaliknya orang yang memiliki efikasi diri karir yang rendah akan mengurangi usaha mereka untuk bekerja dalam situasi yang sulit.

Berdasarkan paparan diatas, penulis tertarik untuk melakukan penelitian tentang apakah ada hubungan antara efikasi diri karir dengan kematangan karir pada siswa kelas XII SMKN 2 Jepara. 


\section{METODE PENELITIAN}

\section{Jenis Penelitian}

Jenis penelitian yang digunakan adalah penelitian kuantitatif dengan desain korelasional.

\section{Variabel Penelitian}

\section{Variabel Bebas (X) : Efikasi Diri Karir.}

Hacket dan Betz (dalam Bandura, 1997) mendefinisikan efikasi diri karir sebagai keyakinan atau kepercayaan individu terhadap kemampuannya untuk mencapai tugas karir yang harus dilalui sesuai rentang usia perkembangan karir yang dihadapi. Variabel efikasi diri karir diukur dengan career decision making self-efficacy scale yang dibuat oleh Taylor Betz (1983) (dalam Bandura, 1997) yang mengacu pada dimensi (a) self-appraisal (penilaian diri), (b) gathering occupational information (pengumpulan informasi bidang karir), (c) goal selection (seleksi tujuan), (d) planning for the future (rencana masa depan), (e) problem solving (pemecahan masalah).

\section{Variabel Terikat (Y) : Kematangan Karir}

Crites (1973) mendefinisikan kematangan karir sebagai tingkat yang dimiliki saat individu telah menguasai tugas perkembangan karirnya, baik komponen pengetahuan maupun sikap, yang sesuai dengan tahap perkembangan karir. Variabel kematangan karir diukur dengan career maturity inventory yang dibuat oleh Crites dan Savickas yang mengacu pada dimensi (a) Konsistensi pemilihan karir, (b) Realisme dalam pemilihan karir, (c) Kompetensi pemilihan karir, (d) Sikap dalam pemilihan karir.

\section{Populasi dan Sampel Penelitian}

Jumlah siswa kelas XII SMKN 2 adalah dijelaskan dalam tabel dibawah ini:

\begin{tabular}{llll}
\hline No & Jurusan & Populasi & Sampel \\
\hline 1. & Animasi & 67 & 25 \\
\hline 2. & Tata Busana & 76 & 29 \\
\hline 3. & Logam & 97 & 37 \\
\hline 4. & Kayu & 64 & 24 \\
\hline 5. & Keramik & 38 & 14 \\
\hline 6. & Tekstil & 70 & 27 \\
\hline 7. & Furniture & 39 & 15 \\
\hline & Total & 451 & 171 \\
\hline
\end{tabular}

Penulis mengambil sampel dengan menggunakan tabel penentuan jumlah sampel berdasar rumus dari Isaac dan Michael dimana menggunakan taraf kesalahan 10\% dari populasi yaitu $10 \%$ dari 451 adalah 171 orang. Jadi, sampel yang digunakan oleh penulis yaitu 171 orang dengan mengambil perwakilan samper per kelas Tata Busana 29 orang, kelas Animasi 25 orang, kelas Logam 37 orang, kelas Kayu 24 orang, kelas Keramik 14 orang, kelas 
Tekstil 27 orang, dan kelas Furniture 15 orang, yang pengambilannya dengan cara undian atau acak.

\section{Metode Pengumpulan Data}

Alat ukur dalam penelitian ini menggunakan dua skala, yaitu Skala Efikasi Diri Karir dan Skala Kematangan Karir. Alat ukur yang digunakan untuk mengukur efikasi diri karir adalah skala yang dibuat oleh Taylor dan Betz (1983) dengan menerapkan teori efikasi diri dari Bandura (1997) yaitu, Career Decision Making Self-Efficacy Scale, kemudian diadaptasi oleh penulis ke dalam bahasa Indonesia dan disesuaikan dengan kepentingan penelitian. Alat ukur yang digunakan untuk mengukur kematangan karir adalah skala yang dibuat oleh Crites dan Savickas (2011) yaitu, Career Maturity Inventory. Pengambilan data menggunakan try out atau uji coba terpakai yang berarti data dari subjek yang digunakan untuk try out juga digunakan untuk penelitian.

\section{Skala Kematangan Karir}

Skala ini mengacu pada Career Maturity Inventory (CMI) yang disusun oleh Crites dan Savickas pada tahun 2011. Skala ini memiliki 24 item pernyataan, dengan lima pilihan jawaban yaitu Sangat Tidak Sesuai (STS), Tidak Sesuai (TS), Tidak Daapt Menentukan Dengan Pasti (TP), Sesuai (S), dan Sangat Sesuai (SS). Sistem penilaian pada skala ini yaitu aitem favorable diberi nilai 1 untuk Sangat Tidak Sesuai (STS), nilai 2 untuk Tidak Sesuai (TS), nilai 3 untuk Tidak Pasti (TP), nilai 4 untuk Sesuai (S), dan nilai 5 untuk Sangat Sesuai (SS). Selanjutnya untuk aitem unfavorable adalah kebalikannya, yaitu nilai 5 untuk Sangat Tidak Sesuai (STS), nilai 4 untuk Tidak Sesuai (TS), nilai 3 untuk Tidak Dapat Menentukan Dengan Pasti (TP), nilai 2 untuk Sesuai (S), dan nilai 1 untuk Sangat Sesuai (SS). Setelah dilakukan analisis item yaitu daya beda/diskriminasi item melalui corrected item-total correlation diperoleh item gugur sebanyak 8 item dan item yang memiliki daya beda yang baik ( $r$ it $\geq 0.30$ ) sebanyak 16 item. Adapun item yang gugur tersebut adalah nomer: $4,5,8,12$, 13, 17, 20, 24.

\section{Tabel 1.1 Reliabilitas Skala Kematangan Karir}

\begin{tabular}{ll}
\hline Cronbach's Alpha & $\mathrm{N}$ of Items \\
\hline .849 & 16 \\
\hline
\end{tabular}

Berdasarkan hasil uji reliabilitas tabel diatas, diketahui bahwa item variabel kematangan karir dari 24 item menjadi 16 item memiliki nilai diskriminasi aitem yang bergerak dari 0,381 sampai 0,647 dengan koefisien Cronbach's alpha sebesar 0,849 sehingga skala kematangan karir dinyatakan reliabel.

\section{Skala Efikasi Diri Karir}

Untuk mengukur variabel efikasi diri karir, digunakan skala yang mengacu pada Career Decision Making Self-Efficacy Scale yang dibuat oleh Taylor dan Betz (1983) dengan 
menerapkan teori efikasi diri dari Bandura (1997). Skala ini memiliki 25 item pernyataan dengan lima pilihan jawaban yaitu Sangat Tidak Sesuai (STS), Tidak Sesuai (TS), Tidak Dapat Menentukan Dengan Pasti (TP), Sesuai (S), dan Sangat Sesuai (SS). Sistem penilaian pada skala ini, aitem favorable diberi nilai 1 untuk Sangat Tidak Sesuai (STS), nilai 2 untuk Tidak Sesuai (TS), nilai 3 untuk Tidak Dapat Mennetukan Dengan Pasti (TP), nilai 4 untuk Sesuai (S), dan nilai 5 untuk Sangat Sesuai (SS). Setelah dilakukan uji daya diskriminasi melalui corrected item-total correlation diperoleh item gugur sebanyak 5 item dan item yang memiliki daya beda/diskriminasi yang baik $(r \geq 0,30)$ sebanyak 20 item. Adapun item yang gugur tersebut adalah nomer: 8, 11, 13, 15, 17.

\section{Tabel 1.2 Reliabilitas Skala Efikasi Diri Karir}

\begin{tabular}{ll}
\hline Cronbach's Alpha & $\mathrm{N}$ of Items \\
\hline .826 & 20 \\
\hline
\end{tabular}

Berdasarkan hasil uji reliabilitas tabel diatas, diketahui bahwa jumlah item variabel efikasi diri karir dari 25 item menjadi 20 item memiliki nilai daya diskriminasi aitem yang bergerak dari 0,265 sampai 0,632 dengan koefisien Cronbach's alpha sebesar 0,826 sehingga skala efikasi diri karir dinyatakan reliabel.

\section{Teknik Analisis Data}

Metode analisis data yang digunakan adalah correlation product moment dari Karl Pearson, dengan bantuan program statistik SPSS versi 16.0 for Windows.

\section{HASIL DAN PEMBAHASAN}

\section{Analisa Deskriptif}

\section{a. Kematangan Karir}

Variabel kematangan karir memiliki item dengan daya diskriminasi baik berjumlah 16 item, dengan jenjang skor antara 1 sampai dengan 5. Pembagian skor tertinggi dan terendah adalah sebagai berikut:

Skor tertinggi : $5 \times 16=80$

Skor terendah : $1 \times 16=16$

Pembagian interval dilakukan menjadi lima kategori, yaitu sangat tinggi, tinggi, sedang, rendah, dan sangat rendah. Pembagian interval dilakukan dengan mengurangi jumlah skor tertinggi dengan jumlah skor terendah dan membaginya dengan jumlah kategori.

$$
\begin{gathered}
i=\frac{\text { jumlah skor tertinggi }- \text { jumlah skor terendah }}{\text { jumlah kategori }} \\
\qquad \begin{aligned}
i=\frac{80-16}{5} \\
i=12,8
\end{aligned}
\end{gathered}
$$


Berdasarkan hasil tersebut, dapat ditentukan interval dan kategori kematangan karir sebagai berikut:

Tabel 1.3 Kategorisasi Hasil Pengukuran Skala Kematangan Karir

\begin{tabular}{|c|c|c|c|c|}
\hline Kematangan $\mathrm{k}$ & & $\mathrm{F}$ & $\%$ & Mean \\
\hline $67,2<X \leq 80$ & Sangat Tinggi & 16 & 9,36 & \multirow{6}{*}{53,93} \\
\hline $54,4<X \leq 67,2$ & Tinggi & 57 & 33,33 & \\
\hline $41,6<X \leq 54,4$ & Sedang & 86 & 50,29 & \\
\hline $28,8<X \leq 41,6$ & Rendah & 10 & 5,85 & \\
\hline $16 \leq X \leq 28,8$ & Sangat Rendah & 2 & 1,17 & \\
\hline Total & & 171 & 100 & \\
\hline
\end{tabular}

Dari tabel diatas dapat dilihat bahwa sebagian besar responden $(50,29 \%)$ memiliki kematangan karir dengan kategori sedang.

\section{b. Efikasi Diri Karir}

Variabel efikasi diri karir memiliki item dengan daya diskriminasi baik berjumlah 20 item, dengan jenjang skor antara 1 sampai dengan 5. Pembagian skor tertinggi dan terendah adalah sebagai berikut:

Skor tertinggi : $5 \times 20=100$

Skor terendah : $1 \times 20=20$

Pembagian interval dilakukan menjadi lima kategori, yaitu sangat tinggi, tinggi, sedang, rendah, dan sangat rendah. Pembagian interval dilakukan dengan mengurangi jumlah skor tertinggi dengan jumlah skor terendah dan membaginya dengan jumlah kategori.

$$
\begin{gathered}
i=\frac{\text { jumlah skor tertinggi }- \text { jumlah skor terendah }}{\text { jumlah kategori }} \\
i=\frac{100-20}{5} \\
i=16
\end{gathered}
$$

Berdasarkan hasil tersebut, dapat ditentukan interval dan kategori efikasi diri karir

\begin{tabular}{|c|c|c|c|c|}
\hline Efikasi Diri Karir & & $\mathrm{F}$ & $\%$ & Mean \\
\hline $84<X \leq 100$ & Sangat Tinggi & 63 & 36,84 & \multirow{6}{*}{80,52} \\
\hline $68<x \leq 84$ & Tinggi & 98 & 57,31 & \\
\hline $52<X \leq 68$ & Sedang & 10 & 5,848 & \\
\hline $36<x \leq 52$ & Rendah & 0 & 0 & \\
\hline $20 \leq X \leq 36$ & Sangat Rendah & 0 & 0 & \\
\hline Total & & 171 & 100 & \\
\hline
\end{tabular}
sebagai berikut:

Tabel 1.4 Kategorisasi Hasil Pengukuran Skala Efikasi Diri Karir

Dari tabel diatas dapat dilihat bahwa sebagian besar responden $(57,31 \%)$ memiliki efikasi diri karir dengan kategori tinggi. 
Uji Asumsi

Tabel 1.5 Uji Normalitas

\begin{tabular}{llll}
\hline \multicolumn{2}{l}{ One-Sample Kolmogorov-Smirnov Test } & & \\
\hline \multicolumn{1}{l}{$\mathrm{N}$} & & EFIKASI & KEMATANGAN \\
\hline Normal Parameters $^{\mathrm{a}}$ & Mean & 171 & 171 \\
\cline { 2 - 4 } & Std. Deviation & 80.5263 & 53.9298 \\
\hline Most Extreme Differences & Absolute & 7.53058 & 8.84213 \\
\cline { 2 - 4 } & Positive & .098 & .070 \\
\cline { 2 - 4 } & Negative & .060 & .070 \\
\hline Kolmogorov-Smirnov Z & & -.098 & -.069 \\
\hline Asymp. Sig. (2-tailed) & & 1.284 & .914 \\
\hline
\end{tabular}

Uji normalitas bertujuan untuk mengetahui normal atau tidaknya distribusi data masing-masing variabel. Dari hasil uji normalitas menunjukkan bahwa data berdistribusi normal, pada variabel kematangan karir diperoleh K-S-Z 0.914, nilai sig. 0.373 ( $p>0,05$ ), pada variabel efikasi diri karir diperoleh K-S-Z 1.284, nilai sig. 0.074 ( $p>0,05)$.

\section{Uji Linearitas}

Tabel 1.6 Uji Linear Efikasi Diri Karir Dengan Kematangan Karir

\begin{tabular}{|c|c|c|c|c|c|c|c|}
\hline & & & $\begin{array}{l}\text { Sum } \\
\text { Squares }\end{array}$ & of $\mathrm{df}$ & $\begin{array}{l}\text { Mean } \\
\text { Square }\end{array}$ & $\mathrm{F}$ & Sig. \\
\hline \multirow{5}{*}{$\begin{array}{l}\text { EFIKASI DIRI KARIR } \\
{ }^{*} \text { KEMATANGAN } \\
\text { KARIR }\end{array}$} & Between Groups & (Combined) & 4577.648 & 38 & 120.464 & 1.944 & .003 \\
\hline & & Linearity & 2539.309 & 1 & 2539.309 & 40.988 & .000 \\
\hline & & $\begin{array}{l}\text { Deviation } \\
\text { from } \\
\text { Linearity }\end{array}$ & 2038.339 & 37 & 55.090 & .889 & .652 \\
\hline & Within Groups & & 8177.662 & 132 & 61.952 & & \\
\hline & Total & & 12755.310 & 170 & & & \\
\hline
\end{tabular}

Hasil uji linearitas menunjukkan adanya hubungan yang linear antara efikasi diri karir dengan kematangan karir dengan deviation from linearity sebesar $F=0.889$, nilai sign. $=0.652$ $(p>0,05)$.

\section{Uji Korelasi}

Dari hasil uji asumsi yang menunjukkan bahwa data yang diperoleh berdistribusi normal dan variabel-variabel penelitian memiliki hubungan linear, maka dalam penelitian ini menggunakan uji korelasi statistik parametik. Uji korelasi yang digunakan dalam penelitian ini adalah korelasi produk moment dari Pearson. 
Tabel 1.7 Uji Korelasi Efikasi Diri Karir Dengan Kematangan Karir

\begin{tabular}{llll}
\hline \multicolumn{1}{c}{ Correlations } & & \\
\hline EFIKASI & & EFIKASI & KEMATANGAN \\
\cline { 2 - 4 } & Searson Correlation & 1 & $.381^{* *}$ \\
\cline { 2 - 4 } & $\mathrm{N}$ & .000 \\
\hline KEMATANGAN & Pearson Correlation & $.381^{* *}$ & 1 \\
\cline { 2 - 4 } & Sig. (1-tailed) & .000 & 171 \\
\cline { 2 - 4 } & $\mathrm{N}$ & 171 & 171 \\
\hline${ }^{* *}$. Correlation is significant at the 0.01 level (1-tailed). \\
\hline
\end{tabular}

Dari hasil uji korelasi pada tabel 1.7 menunjukkan bahwa ada hubungan positif signifikan antara efikasi diri karir dengan kematangan karir dengan $r=0.381$ dan nilai signifikan $0.000(p<0,05)$. Bisa diartikan hipotesis dalam penelitian ini diterima. Makin tinggi efikasi diri karir maka makin tinggi juga kematangan karir yang dimiliki pada siswa kelas XII SMKN 2 Jepara. Demikian sebaliknya, makin rendah efikasi diri karir maka makin rendah juga kematangan karir yang dimiliki. Sumbangan efektif efikasi diri terhadap munculnya kematangan karir sebesar $14,52 \%$ ditunjukkan oleh koefisien determinan $\left(r^{2}\right)$ sebesar 0,381 .

\section{PEMBAHASAN}

Berdasarkan hasil uji perhitungan korelasi dengan $r=0.381$ serta nilai signifikan sebesar $0.000(p<0,05)$ berarti kedua variabel efikasi diri karir dengan kematangan karir memiliki hubungan positif yang signifikan, dimana dengan demikian hipotesis yang diajukan peneliti yang menyebutkan bahwa ada hubungan positif dan signifikan antara efikasi diri karir dengan kematangan karir pada siswa kelas XII SMKN 2 Kab. Jepara dapat dikatakan diterima. Makin tinggi efikasi diri karir, maka makin tinggi pula kematangan karir yang dimiliki. Begitu juga sebaliknya, makin rendah efikasi diri karir, maka makin rendah pula kematangan karir yang dimiliki pada siswa kelas XII SMKN 2 Jepara.

Hasil dari penelitian ini mendukung beberapa penelitian sebelumnya yang pernah dilakukan oleh Nur (2015) yang menemukan adanya hubungan positif yang signifikan antara efikasi diri karir dengan kematangan karir pada siswa kelas XII SMAN 1 Karanganyar Demak. Kemudian penelitian Sersiana (2013) yang membuktikan bahwa ada hubungan yang positif dan signifikan antara efikasi diri karir dengan kematangan karir pada siswa SMK PGRI Wonosari. Juga penelitian Fauzan (2016) yang menjelaskan bahwa ada hubungan positif signifikan antara efikasi diri dengan kematangan karir pada siswa kelas XI SMKN 5 Pangkalpinang. 
Nur (2015) menyatakan bahwa salah satu faktor yang berpengaruh pada kematangan karir adalah efikasi diri. Semakin tinggi efikasi diri karir siswa maka semakin tinggi juga tingkat kematangan karir siswa tersebut. Menurut Bandura (dalam Fauzan, 2016) seseorang yang memiliki efikasi diri karir yang tinggi percaya bahwa ia mampu melakukan sesuatu untuk mengubah kejadian-kejadian disekitarnya. Dengan memiliki efikasi diri karir yang tinggi ketika dihadapkan pada pemilihan karir, maka ia akan melakukan usaha untuk mengetahui kemampuan pada dirinya atau mengenal diri, mencari tahu tentang pekerjaan dan langkahlangkah pendidikan, dan berusaha mengatasi masalah yang menghambat dirinya. Seseorang dengan efikasi diri karir yang tinggi akan dapat menentukan tujuan atau target untuk dirinya yang akhirnya dapat menjadi penentu keberhasilan dalam menjalankan tugas-tugasnya, selain itu juga akan mempunyai kesiapan mental untuk belajar, lebih mempunyai dorongan yang kuat untuk terus belajar giat, dan lebih tahan dalam mengatasi kesulitan. Hal ini akan berpengaruh terhadap kematangan karir yaitu akan lebih siap kaitannya dengan persiapan karir untuk masa depannya kelak, sedangkan seseorang yang memiliki efikasi diri karir yang rendah menganggap dirinya pada dasarnya tidak mampu mengerjakan segala sesuatu yang ada di sekitarnya. Hal ini menunjukkan orang yang memiliki efikasi diri karir yang rendah akan cenderung untuk pasrah dan mudah menyerah sehingga akan berpengaruh terhadap kematangan karir yang dimiliki.

Menurut Widjaja (2010), dalam proses mencapai kematangan karir, siswa perlu mempunyai keyakinan tentang dirinya akan karir, yakin dengan ciri-ciri kepribadian yang menonjol, yakin akan potensi intelektualnya, dan yakin dengan kelebihan yang dimiliki yang membedakannya dari siswa lain, serta dapat menerima perbedaan tersebut. Selain itu siswa harus menentukan dengan tepat bidang karir dan jenis pekerjaan yang sesuai dengan kemampuan mereka. Pervin (dalam Widjaja, 2010), mengatakan bahwa efikasi diri karir yang rendah berhubungan dengan proses mencapai kematangan karir, kebimbangan dalam pembuatan keputusan karir, masalah-masalah dalam mengembangkan identitas vokasional/kejuruan yang jelas, dan ketidakpastian dalam menentukan pilihan. Siswa yang memiliki efikasi diri karir yang tinggi, akan merasa mampu untuk melaksanakan tugas perkembangan karir yang dihadapinya sehingga mencapai kematangan karir. Hal tersebut disebabkan karena dengan efikasi diri karir, siswa akan berusaha keras untuk menghadapi kesulitan, termasuk di dalamnya kesulitan dalam mencapai kematangan karir seperti banyaknya pilihan alternatif pekerjaan. Menurut Bandura (Pinasti, 2011) orang yang memiliki efikasi diri karir yang tinggi, akan mengeluarkan usaha yang besar untuk mengatasi hambatan dalam mencapai tujuannya. Hal tersebut yang menyebabkan individu memiliki efikasi diri karir yang lebih tinggi akan siap menentukan karir yang tepat untuk dirinya dibandingkan dengan individu yang memiliki efikasi diri karir yang rendah. 
Terdapat beberapa ciri-ciri yang dapat menandai kematangan karir yang positif, yaitu meningkatnya self awareness, meningkatnya pengetahuan mengenai pilihan yang relevan, meningkatnya kongruensi antara self-image (kemampuan, minat, nilai-nilai, kepribadian) dan tujuan karir yang semakin realistis (Seligman dalam Hawadi \& Komandyahrini, 2008). Selain itu, ditandai dengan meningkatnya kompetensi untuk membuat perencanaan terkait karir dan kesuksesan karir, mengembangkan sikap positif terkait karir (orientasi terhadap pencapaian, kemandirian, penuh pertimbangan, komitmen, motivasi dan efikasi diri). Kematangan karir mengandung makna bahwa siswa mampu menyelesaikan tugas perkembangannya saat ini yaitu mengerjakan tugas-tugas dan menjalankan sekolah dengan serius agar dapat segera menentukan karir yang sesuai dengan minat dan kemampuan.

Dari hasil perhitungan yang diperoleh bahwa efikasi diri karir memiliki sumbangan efektif terhadap munculnya kematangan karir sebesar $14,52 \%$ ditunjukkan oleh koefisien determinan $\left(r^{2}\right)$ sebesar 0,381 . Hal ini menunjukkan terdapat $85,48 \%$ faktor lain yang mempengaruhi kematangan karir, yaitu harga diri, self-expectation, locus of control, keterampilan, minat, bakat, kepribadian, dan usia (Seligman, 1994).

\section{SIMPULAN}

Berdasarkan penelitian yang telah dilakukan tentang hubungan efikasi diri karir dengan kematangan karir pada siswa kelas XII SMKN 2 Jepara maka dapat disimpulkan:

1. Ada korelasi positif yang signifikan antara efikasi diri karir dengan kematangan karir pada siswa kelas XII SMKN 2 Jepara, yang berarti bahwa makin tinggi efikasi diri karir siswa maka makin tinggi pula kematangan karir yang dimiliki, begitu juga sebaliknya makin rendah efikasi diri karir siswa maka makin rendah pula kematangan karir yang dimiliki.

2. Sebagian besar siswa $(57,31 \%)$ kelas XII SMKN 2 Jepara memiliki efikasi diri karir yang tergolong pada kategori tinggi dan sebagian besar siswa $(50,29 \%)$ memiliki kematangan karir yang tergolong pada kategori sedang.

3. Sumbangan efektif efikasi diri karir terhadap munculnya kematangan karir sebesar $14,52 \%$

\section{SARAN}

Dengan hasil penelitian diatas, maka peneliti mengajukan saran bagi beberapa pihak sebagai berikut:

1. Bagi Siswa

Siswa yang mempunyai efikasi diri karir yang tinggi, diharapkan mampu mempertahankannya agar kematangan karir yang dimiliki semakin baik. Untuk meningkatkan kematangan karir bagi siswa yang masuk dalam kategori sedang, dapat diperoleh dengan 
cara, antara lain dengan melakukan hal-hal sebagai berikut:

a. Dapat merencanakan karir di masa depan.

b. Merencanakan pilihan karir yang sesuai dengan kemampuannya.

c. Dapat mengambil keputusan dengan benar mengenai karir yang dipilih.

d. Dapat mempertimbangkan pilihan pendidikan dan karir dengan baik.

2. Bagi Guru Bimbingan dan Konseling

Guru BK disarankan untuk lebih banyak memberikan bimbingan maupun konseling terhadap siswa mengenai efikasi diri karir dan kematangan karir. Bimbingan maupun konseling efikasi diri karir berupa penguatan keyakinan diri yang dimiliki terhadap karir, tidak mudah menyerah menghadapi kegagalan, serta mampu menghadapi berbagai situasi permasalahan yang komplek, serta bimbingan atau konseling kematangan karir yang berupa konsistensi pemilihan karir, realisme dalam pemilihan karir, kompetensi pemilihan karir, dan sikap dalam pemilihan karir.

3. Bagi Penelitian Selanjutnya

Berdasarkan hasil penelitian, peneliti selanjutnya dapat meneliti lebih dalam mengenai hubngan kematangan karir dengan variabel lain selain efikasi diri karir, misalnya faktor lingkungan, faktor keluarga, dan kepribadian meliputi harga diri, self-expectation, locus of control, keterampilan, minat, bakat, kepribadian, dan usia.

\section{DAFTAR PUSTAKA}

Putri, A.W. (2018). 2018 Jadi Tahun yang Buruk Bagi Korban Kekerasan Seksual. Tirto.id. di unduh pada tanggal 10 Januari 2017

Aji, R., Hartati, S., \& Rusmawati, D. (2010). Hubungan antara locus of control internal orang: Fakultas Psikolgi. UNDIP.

Bandura, A. (1997). Self-efficacy in changing societies. New York: Cambridge University Press.

Crites, J. O. (1973). Career maturity. National Council on Measurement in Education, 4(2), 19.

Lestari, W. T. (2013). Relationship between self efficacy with career maturity at the end college students. Emphaty Jurnal Fakultas Psikologi, 2(1), 1-12.

Pajares, F. (2006). Self-beliefs and school success: Self-efficacy, self-concept, and school achievement. In R. Riding \& S. Rayner (Eds.), Perception (pp. 239-266). London: Ablex Publishing.

Partino. (2005). Kematangan karir siswa SMA. Jurnal Psikologika, 11(21), 37-50.

Peraturan Pemerintah Republik Indonesia. (1990). Undang-Undang no. 29 tahun 1990 tentang pendidikan menengah. Lembaran Negara RI tahun 1990, no 37. Sekretariat Negara. Jakarta. 
Pinasti, W. (2011). Pengaruh self-efficacy, locus of control dan factor demografis terhadap kematangan karier mahasiswa uin syarif hidayatullah Jakarta. Skripsi. Fakultas Psikologi. Jakarta: UIN.

Prihantoro, S. (2007). Program bimbingan untuk mengembangkan kemampuan perencanaan karir remaja (Studi terhadap siswa kelas X SMAN 2 Majalengka tahun ajaran 2005/2006). Skripsi. Fakultas Psikologi. Universitas Pendidikan Indonesia.

Rachmawati, Y. E. (2012). Hubungan antara self-efficacy dengan kematangan karir mahasiswa tingkat awal dan tingkat akhir di Universitas Negeri Surabaya. Jurnal IImiah Mahasiswa Universitas Negeri Surabaya, 1(1), 1-25.

Rishadi, F. (2016). Hubungan antara efikasi diri dengan kematangan karir pada siswa kelas XI SMKN 5 Pangkalpinang tahun ajaran 2015/2016. E-Jurnal Bimbingan dan Konseling, 3(5), 51-59.

Seligman, L. (1994). Developmental career counseling and assessment (2nd Ed). New York: Sage Publications, Inc.

Sersiana, L., Lukitaningsih, R., Luis, T., \& Purwoko, B. (2013). The relationship between career self efficacy and perception towards career future and career maturity on the students of SMK PGRI Wonosari in the academic year of 2012/2013. Jurnal BK UNESA,3, 172-180.

Super, D. E. (1980). A life-span, life-space approach to career development. Journal of Vocational Behavior, 16, 282-298.

Susantoputri, Kristina, M., \& Gunawan, M. (2014). Hubungan antara efikasi diri karier dengan kematangan karier pada masa remaja di daerah kota Tangerang. Jurnal Psikologi, 10, 67-73.

Taylor, K. M., \& Betz, N. E. (1983). Applications of self-efficacy theory to the understanding and treatment of career indecision. Journal of Vocational Behavior, 22, 63-81.

Umam, N. A. A. (2015). Hubungan antara self efficacy karir dengan kematangan karir siswa kelas XII SMAN 1 Karanganyar Kab. Demak. Skripsi. Fakultas Psikologi. Semarang: UNIKA.

Warsito, H. (2009). Hubungan antara self-efficacy dengan penyesuaian akademik dan prestasi akademik. Jurnal IImiah IImu Pendidikan, 9(1), 3-4.

Wijaya. F. (2010). Hubungan antara kematangan karir dengan motivasi belajar pada siswa kelas X MAN Cibinong. Skripsi. Fakultas Psikologi. UNTAG.

Zulkaida, A., Retnaningsih, \& Muluk, H. (2007). Pengaruh locus of control dan efikasi diri terhadap kematangan karir siswa sekolah menengah atas (SMA). Proceeding PESAT (Psikologi, Ekonomi, Sastra, Arsitek, \&Sipil), 2, 21-22. 